心 X 線の角度, すなわち滕蓋骨の上下極を軽量小型化し た補助具で計測し，そのなす角度を付属してい当角度計 にて值読し，その角度を X 線中心入射角とした。この補 助具を同一患者の膝蓋大腿関節の傾きを 6 人の放射線技 師によって測定したが個人差は特に認められなかった。

\section{0. 頸椎前後撮影の検討}

立正佼成会附属佼成病院放射線科

○酒井久恵・神田幸助・渡辺雅弘

〔目的〕頸椎前後撮影には, 種々の撮影法が存在し, 現在各施設でそれぞれ異った撮影法が用いられているが， わずかの角度や入射点の違い等により部分的に歪を生ず 等, 頸椎前後位の基本的情報である椎体の大きさ・ルシ ュ力関節・椎間間隙などを全て正投影に近いものとして 得ることはむづかしく，このため内部構造から検討した 撮影法により良好な情報を供給することが可能となった ので報告する。

〔結果〕上側前歯と外後頭隆起を Film 面に対し垂直 とし，X 線を足頭方向より $\mathrm{C}_{4}$ に向けて $10^{\circ}$ 斜入する撮影 法により，頸椎正面像に抢ける基本的臨床情報を満たし， 最も正投影に近い像が得られる。

\section{1. 上顎洞 X 線写真陰影の定量的測定（第 3 報）}

東京大学医学部附属病院

○小山昌二郎・洲崎春海・一村 梓

野島 傊・中嶋信義・佐竹芳朗

福田実

小西六写真工業(株) 中丸三次

第39・40回総会に報告した上顎洞陰影定量化の方法に おいて，さらに頭部の傾斜によって与えられる影響を検 討した。ドイツ水平面 $45^{\circ}$ 中心として上下方向に $40^{\circ}$ 〜 $50^{\circ}$ の間で 1 ずつ角度を変化させた場合，ドイツ水平 面 $45^{\circ}$ を一定として左右方向へ $1^{\circ}$ ずつ各々 $5^{\circ}$ まで変化 させた場合について撮影定量化ののち検討を行った。

上下方向，左右方向いずれの場合も，肉眼的に像の傾 斜が明らかでない範囲（上下方向士 $3^{\circ}$, 左右方向 $\pm 1^{\circ}$ ) においては，定量化上その影響をほぼ無視できた。

22. 断層撮影における濃度補償フィルタの問題点

帝京大学医学部附属病院中央放射線部

○大谷浩之・船木新寿・鈴木 敦 高階孝弘・近松 孝・針替 栄 小川敬寿

現在，断層撮影に扔ける濃度補償で，多種絞り前面に 楔型フィルタを取り付ける方法とファントム型補償フィ ル夕を被写体と平行に移動させる方法に付いて考察した 結果, 平板型では X 線管の移動, 裁断面の変化に従い異
常陰影が出現し，ファントム型では X 線管の移動に供な う異常陰影は改善されても，裁断面移動に供なり問題が 残るので裁断面の移動に合わせて，フィル夕を移動させ ることを志れてはならない。断層撮影に㧍いて上記の問 題を認識しつつ形状・使用方法に留意し, 頚椎, 股関節 等, 被写体厚に依存する補償部位では，ボーラス等手軽 で簡便な方法がより良いものと考える。

\section{座長集約}

今回の演題群は日常の身近な内容が多く興味深かつた。 16席のローリング効率については，Baの附着を高为 ことが目的であるから，ローリングの回数もさることな がら，Baの附着や流出にはローリング速度や体位変換 の難易度等も関係するので，をれらを考慮に人れた内容 であって欲しかった。17席，20席の画法幾何学的撮影に かては骨を形態的，機能的視点で考慮した考え方をさ れており注目した。個人差の少ないポジショニング，人 射点を理論化できれば，他の部位への導入も可能であり 期待したいと思う。他の演題もそれぞれ身近な内容が多 からたためか，全場における質疑岕答が活発に行なわ机， 大変充実したものであったと思う。

\section{中部部会 $>$}

日 時 昭和 59 年 10 月 13 日 (土)，14日(日)

場 所 大坦市文化会館

\section{特別講演}

$「$ 胆道疾患の診断と治療」

高田忠敬助教授（帝京大学医学部）

\section{研究発表}

「膵疾患の診断と治療」

中野 哲先生（大坦市民病院）

撮影 -1

$$
\text { 座長 安井正.. (富山医科薬科大学) }
$$

\section{1. 小巟胸部撮影装置の試作}

名古屋大学医学部附属病院分院・放射線科

堀部廣恵・堀部泰樹

5 才以下の胸部撮影が $26.3 \%$ 占めている当院におい て小児撮影における再撮，長時間等多くの問題を示して いた。私達は視覚および聴覚に刺激を与える注視固定法 (Fixation) の-環として，小児用胸部撮影装置を試作 し，良好な成果を得たので報告する。

〔方法〕小児用胸部撮影装置 2 号機を用い看護依存率, 再撮件数, 撮影時間, 撮影時における患者動行の測定分 析を施行.

〔結果〕注視固定法の具体的実施により, 再撮件数は 